\title{
Towards a Genealogy of Urban Shopping - Types, Adaptations and Resilience
}

\author{
Fujie Rao, Kim Dovey, and Elek Pafka
}

This typological account of the urban morphology of shopping presents a diagrammatic genealogy of urban retail types from traditional markets, streets and plazas through various adaptations and mutations into the contemporary shopping mall and power centre. This genealogy shows an increased car-dependency, privatized and centralized control, and disintegration from urban life. Many cities have been transformed by contemporary retail types that are less walkable, equitable, productive and resilient than those from which they were derived. The challenge lies in the invention of new retail types with potential for re-integration into more resilient forms of urban development.

Keywords: urban shopping; retail types; diagrammatic genealogy

\section{Introduction}

Shopping has always been central to the very idea of urbanity - cities as sites of exchange. This paper explores the ways in which shopping works in terms of urban morphology. How might different forms of shopping be best conceived of as morphological types? How are these types integrated, or not, with the city and its access networks? How have these types changed over time and how do they adapt and mutate into new types? What is the impact of shopping on the experience of urbanity and how do different retail morphologies mesh with goals for a more walkable, equitable, productive and resilient city?

There is no single standard typology of urban shopping. The most common approaches involve distinctions according to scale, function, control and spatial form (Gibbs 2012; Guy 1998). Typologies of scale generally range from city centre, to town centre, district centre, neighbourhood centre and local shopping centre - categorized according to the size of population and territory from which they draw customers (Berry 1967). Labels indicating scale include 'mega-mall', 'regional mall' and 'convenience centre'. Functional typologies are generally divided first into 'general' versus 'special-purpose' centres, with speciality centres then focused on particular market sectors and products (Fernie 1998; ICSC 2017). For instance, 'outlet malls' and 'big box' centres generally focus on low price and particular product categories. Shopping centres are also sorted according to types and degrees of private and public planning, ownership and control. In the UK, retail centres are often divided into the 'unplanned' and 'planned' (Lowe 2005) or 'evolved' and 'created' (Teller 2008). 'Unplanned' or 'evolved' centres result from an emergent process and contain fragmented ownership while 'planned' or 'created' centres are developed in a coordinated manner, often under single private ownership. These three frameworks for understanding retailing according to scale, function and control are each substantial fields of scholarship and importance. The focus of this paper is on the design and spatial form of urban shopping. Such morphological typologies of urban shopping so far have been limited to a particular type (Geist 1983) or historic period (Pevsner 1976), and they seldom consider the car-based shopping centre emerged in the 20th century. While the spatial form of urban shopping inevitably contains overlaps with issues of scale, function and control, the ultimate concern of this paper is with the impact of retailing on the city - on car-dependency, walkability and social equity; and on the intensity of face-to-face social interaction in urban life.

The research approach is to develop a diagrammatic typology that seeks to understand retailing in terms of diagrammatic socio-spatial relations. A diagram is an abstract image depicting a set of forces in a particular alignment that shows how something works in general terms yet is also geared to the spatialities of 
each instance. Such an approach has its roots in several modes of thought. First, within the traditions of typomorphology the notion of an urban type involves an excavation of the typical forms that combine to shape the city at various scales - the building type, street type and block type (Moudon 1994; Marshall 2005). These are not archetypes nor copies of some original but result from analysis of the 'typical' forms that emerge in different cities and contexts. The type is a form that is repeated through urban history, often unthinkingly, because it has proven to 'work' in some way. Such an approach also has roots in Alexander's notion of 'patterns' that are interconnected through a pattern language (Alexander, Ishikawa, and Silverstein 1977). Each pattern includes a diagrammatic sketch of the forces embedded in different urban contexts - joining the sociality and spatiality into a single diagram of shapes, flows and desires that are shared in typical situations (Alexander, Ishikawa, and Silverstein 1977). The third source of the research approach lies in the application of assemblage thinking to urban design, the attempt to understand the city in terms of relations and flows rather than objects and fixed forms, a focus on synergies and alliances, adaptations and emergent forms (Deleuze and Guattari 1987; DeLanda 2006; Dovey 2010). Here the 'diagram' (the 'abstract machine' to use the jargon) is understood as a set of productive forces and relations embodied in the city. However, this is not a theory paper and the purpose is to deploy such an approach to better understand the repetition, adaptation and mutation of urban shopping; to show how urban shopping works. Diagrams of retail types can help to build a socio-spatial knowledge base and to illuminate the complex interrelations of the sociality, spatiality and economy of retailing.

\section{Diagrams}

In what follows this paper suggests a typology of urban shopping that can be understood as diagrammatic spatial relations within an historic genealogy. At the base of all urban retailing is a spatial relation consisting of a flow of pedestrians past a range of products; this relation is maintained through different retail types that can be seen to adapt, mutate and form synergies within contemporary urban morphologies. All of these retail types have a particular kind of spatial diagram at their core - a flow at a tangent to a product that might be called the 'shopfront interface' (Figure 1). A customer sees (smells, hears, touches) a product and the flow of desire is triggered. This is the core of the spatiality of exchange wherever a producer seeks a market (Dovey 2016, 162). This base diagram explains the spatial distribution of informal trading where the mobile hawker moves to the pedestrian flow. It does not change fundamentally when people speed past billboards with products that can only be purchased much later; nor when magazine, TV, and online shopping lead to products flowing past stationary consumers. The focus here, however, is on walkable shopping, the typical ways it has emerged within and shaped cities, and the ways it is adapting and mutating. The types that will be briefly introduced here are broadly recognizable; while there could be many others, this is not a catalogue but a framework for understanding the genealogy of retailing.

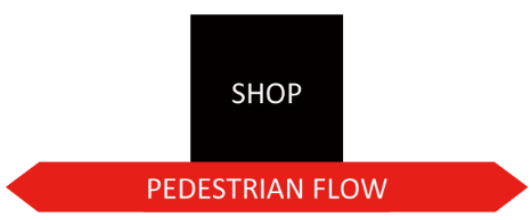

Figure 1. The shopfront interface.

This paper begins with four traditional retail types as described in Figure 2. The traditional 'market network', often a form of temporary urbanism with stalls set up within a plaza or open hall, has the spatial structure of a highly permeable grid where one can navigate in multiple ways through the network - maximizing access to products (Hakim 1986; Pevsner 1976; Wang 2003). The 'plaza' (e.g. market square) is an open public 
space lined with shops, all of which are visible within a single field of vision and accessible from the same space (Kostof 1991). The market often happens within the plaza - these types are often in synergy with each other and with larger urban assemblages. The 'pedestrian street' is essentially a flow of pedestrians lined with stores.

When vehicular traffic is introduced the 'main street' emerges - basically a pair of sidewalks separated by traffic (Kostof 1991). At the larger scale 'downtown' generally becomes a network of main streets - a re-emergence of the diagram of the traditional market. There are many combinations of these types but traditional retailing can be largely seen as variations and synergies of these four.

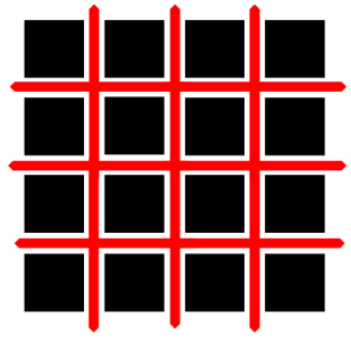

MARKET NETWORK

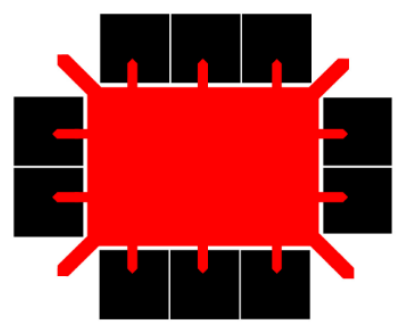

PLAZA / SQUARE / COURT

$$
\begin{array}{ll}
\text { KEY } & \\
& \text { Shops } \\
\text { Pedestrians } \\
\text { Vehicles }
\end{array}
$$

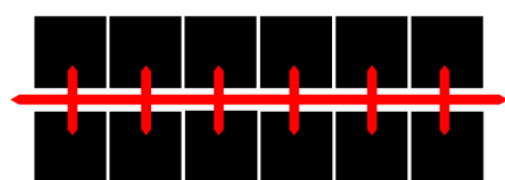

PEDESTRIAN STREET

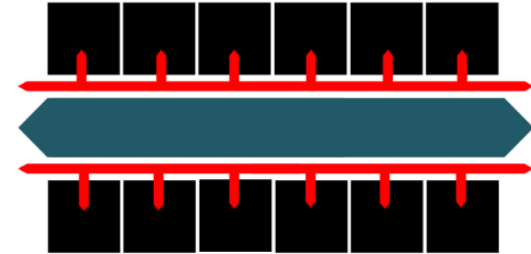

MAIN STREET

Figure 2. Traditional retail types.

Consider now the types that emerged in the 19th century as adaptations to these traditional types (Figure 3). The 'arcade' is a pedestrian street that emerges as a shortcut, generally between two main streets a privately controlled but publicly accessible escape from the traffic-ridden public street (Geist 1983). The 'department store' generally consists of dense networks of pedestrian routes, similar to the traditional market except that it is enclosed and privately controlled (Frieden and Sagalyn 1989; Longstreth 2010). While the market grid is an agglomeration of self-organized entrepreneurs, here the 'departments' are organized as branches of a tree (Ford 2003). While the department store may be considered a store rather than a shopping centre, it is a crucial type within this genealogy as a prelude to the shopping mall and the big box.

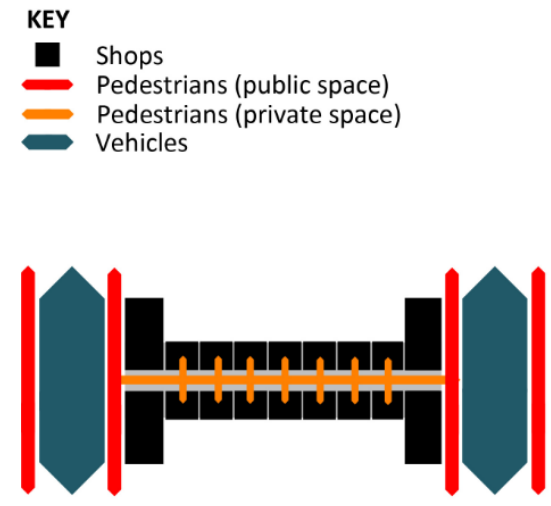

ARCADE

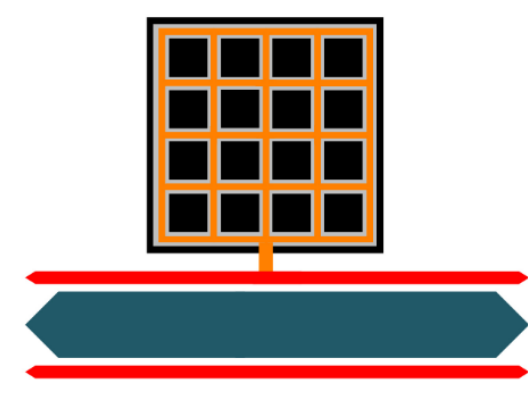

DEPARTMENT STORE 
Figure 3. 19th century types.

In the mid-20th century this paper finds a new range of emergent types (Figure 4). The 'strip mall' is effectively a pedestrian sidewalk that has been set back from the street behind a shared carpark with a variety of store types (Southworth 2005). Strip malls are often located on corners for better access with an L-shaped strip around a common carpark. The suburban shopping mall emerges from the synergy of three retail types: arcade, department store and strip mall. The first move was to locate department stores at both ends of a strip mall with a pedestrian strip between them (Longstreth 1997). However, this allowed people to drive directly to the department store while ignoring the small stores (Gruen and Smith 1960). The more typical suburban mall emerges when the entry from the carpark is channelled through the arcade (Dovey 2008, 139). The original 'dumbbell diagram' has two department stores (anchors/magnets) at the ends of a pedestrian street (or arcade) that is used as the entry passage (Gruen and Smith 1960). Thus it is the synergy of the magnet as attractor and the pedestrian street as entry that artificially produces pedestrian flows. The shopping mall embodies a manipulation of pedestrian traffic to increase impulse consumption - customers are forced to walk further than necessary to get what they want (Crawford 1992).

The anchor stores of the mall are not only derivative of the department store but mark the emergence of 'big box' retailing which includes supermarkets and large specialty stores. The 'big box' is an adaptation of both the market hall and pedestrian street - a large enclosure incorporating pedestrianized networks of stalls and aisles. The big-box is also called a 'category killer' in that it seeks to kill the competition within a particular retail category using a mix of product range and low price (Arnold and Luthra 2000). The big box also forms a key part of the mid-20th century emergence of the car-based 'strip' - a linear agglomeration of retail and other attractions with separate parking; these include big-box retail, fast-food, entertainment venues, motels and service stations (Hernandez et al. 2004; Jakle and Mattson 1981; Venturi, Scott Brown, and Izenour 1977). The strip generally seeks to attract customers with free parking and a minimum distance between parking and product. It differs from the strip mall in having dedicated parking for each shop or venue.

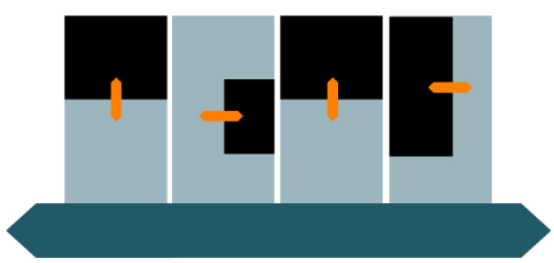

STRIP

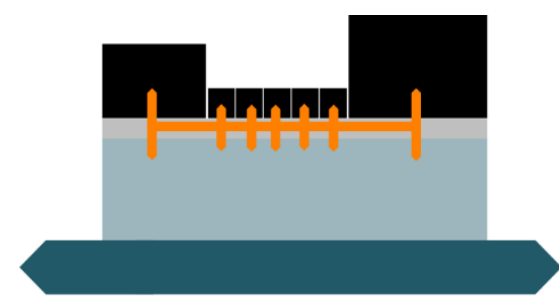

STRIP MALL
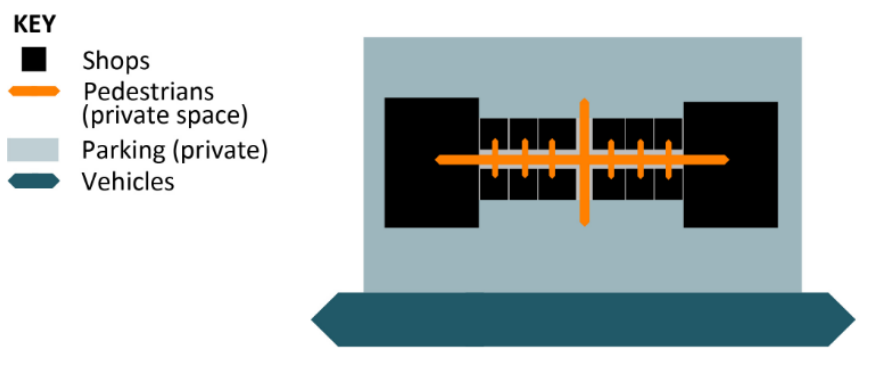

SUBURBAN MALL

Figure 4. Mid-20th century types.

There have been many adaptations of the suburban mall as it mutates and adapts to a range of different attractions and contexts (Leong 2001) - four of them are shown in Figure 5. The first is the 'mega-mall' which can take many forms but what they have in common is the multiplication of anchor stores, pedestrian 
streets and plazas, simulating the complex networks of the traditional city within the heart of the mall - all serviced by a ring of parking (ICSC 2017). The mega-mall is the outcome of competition between malls to gain greater size and retail synergy. Second is the 'cul-de-sac mall' with an attraction at the end. It is effectively just one half of the original dumbbell adapted to any form of urban attraction (Dovey 2016, 162). When the suburban mall returns to the city centre as vertical retailing this diagram often becomes the design driver with an entertainment space (e.g. cinema) at the top as the magnet (Goss 1993; Herman 2001). The pedestrian flows to and from any heritage or tourist site, waterfront or event can be exploited by retailing in this manner (Ford 2003). A similar variation of the cul-de-sac mall occurs within the rapid transit station (e.g. a major urban railway station) where the train becomes the magnet of a pedestrian-only shopping path. A different variation is the one-way 'entry mall' - most commonly found in international airports - where the flight is the attraction and the waiting time creates a captive audience (Sudjic 1992).
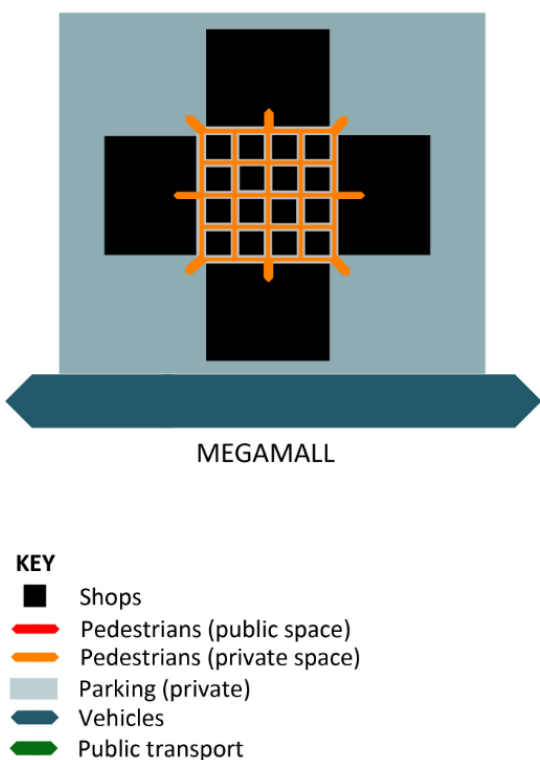
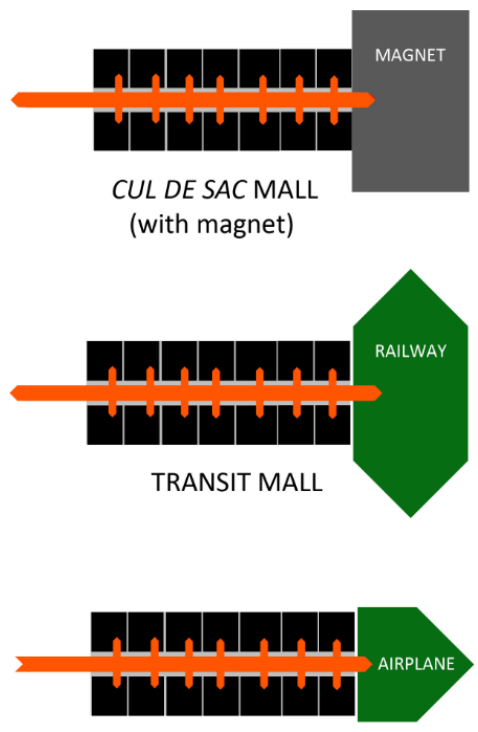

ENTRY MALL

Figure 5. Mall adaptations.

Our final type in this set is the 'power centre' (Figure 6) which combines elements of the strip and the strip mall with the powerful attraction of the big box retailer (Jones and Doucet 2000; Thomas, Bromley, and Tallon 2004). While the big box was often a part of both the strip and strip mall, the separated carparks of the strip required a difficult journey between shops and the linear carpark of the strip mall created limits to its size. The key driver is car-based convenience; the power centre combines the common carpark of the strip mall with the big box attractions of the strip (Hernandez et al. 2004). The power centre competes with the shopping mall in terms of size and price, yet in other ways it is the inverse: a central rather than peripheral carpark; walking is minimized rather than maximized (Lorch 2005). The power centre also works as a single field of vision where the full range of big box outlets are visible across the carpark which is navigated by car rather than on foot (Hahn 2000). The power centre can then be seen as an enlarged diagram of the traditional plaza - privatized and motorized. The power centre, however, involves minimal investment in either architecture or public space and lacks even the ersatz urbanity of the shopping mall. 

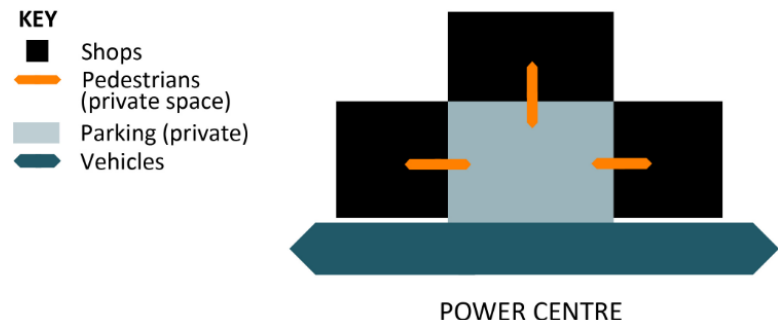

Figure 6. Power centre.

\section{A Genealogy}

There are many other possible and useful ways of categorizing the range of ways shopping becomes manifest in urban morphology - the proposed typology could be extended to incorporate other variations and hybrids, or larger spatial scales (Vance 1990). But consider why this diagrammatic typology might be useful. The diagrams are abstractions that reduce each type to the set of spatial relations through which it works. They are stripped of everything except the direct spatial relations of shops to flows of pedestrians and vehicles - the ways that encounters between consumers and products are structured.

When these diagrams are juxtaposed (Figure 7) a genealogy of retail types is revealed. To keep this simple the various adaptations of the mall have been omitted. The open market, plaza, pedestrian street and main street are all ancient types - typical of retail activity in the earliest of cities. The core diagram of a pedestrian flow past a product (the shopfront) is the key driver of exchange within each of them and it remains so in all of the subsequent types as the larger assemblage of spatial relations is transformed around it. The urban arcade is a development of the late 19th century that is essentially a pedestrian street that generates new flows by providing a shortcut through private space. The department store from the same period draws upon the productive diagram of the open market. The progression from these types to the mid-20th century types is defined by the introduction of parking between the street and the shopping. The strip mall is derived from the main street using a carpark between the street and sidewalk. The suburban shopping mall emerges from the strip mall as a marriage of the department store and the arcade, using the large stores as anchors or magnets to produce pedestrian flows through the connecting pedestrian street. The strip is like the strip mall but with dedicated parking for each store and shopping becomes a matter of driving from store to store. The power centre emerges from the strip and strip mall to incorporate the principle of visibility of the urban plaza. 


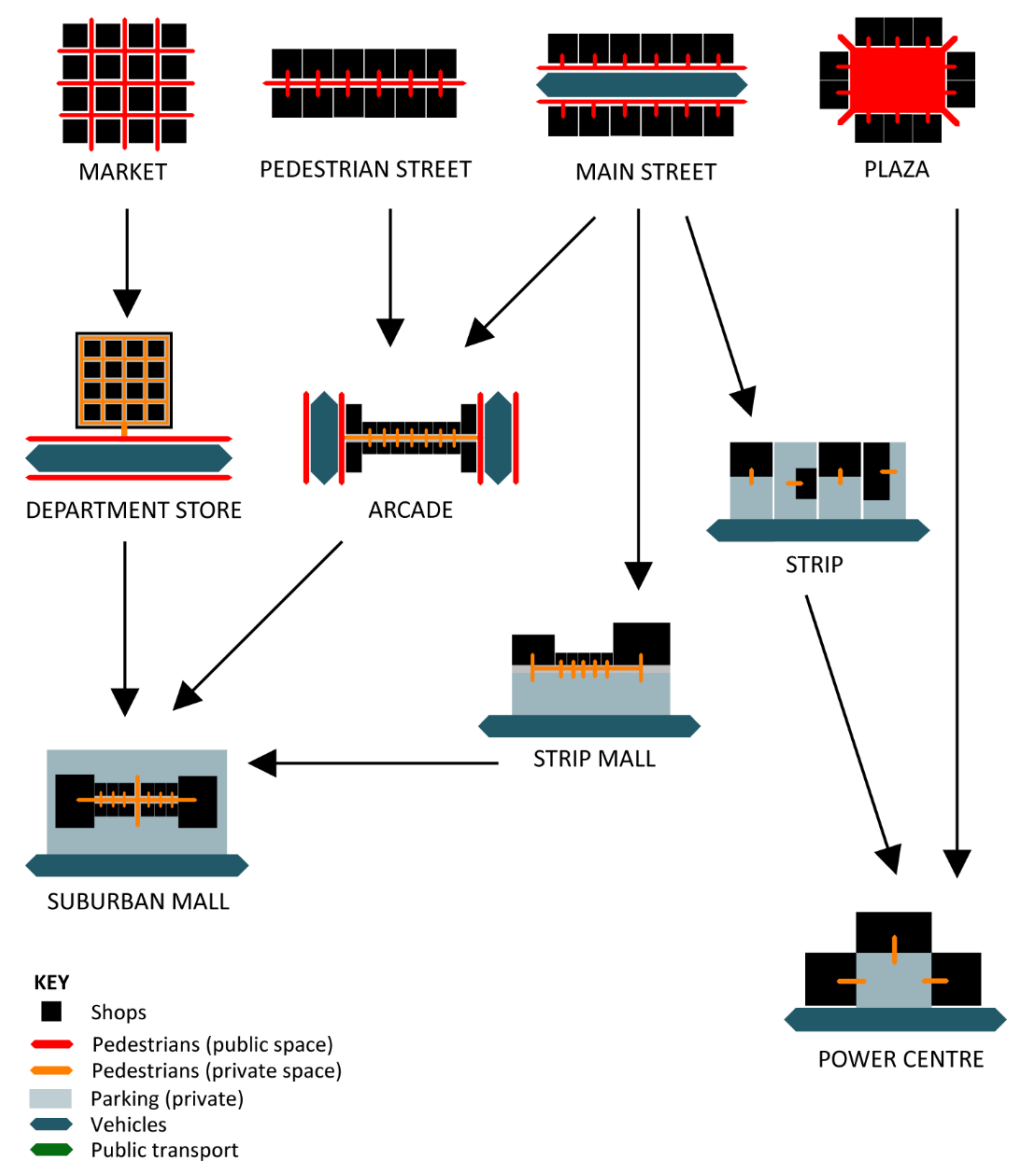

Figure 7. A genealogy of retail types.

This genealogy reveals the ways that traditional spatialities of shopping have been retained and adapted within the later types. The market grid is a crucial component of the success of the department store, big box and mega-mall. The spatial diagrams of the pedestrian street and sidewalk of a main street are crucial to the suburban mall and strip mall. The single field of vision of the plaza is a key asset to the power centre. The genealogy is best understood not as a simple invention of new types but as the adaptation and reconfiguration of four traditional retail types through two 19th century types and then four 20th century types. While the new types do not necessarily replace the earlier ones, this genealogy shows a range of transformations that emerge in the 20th century - a progressive loss of urbanity through increased car-dependency, privatization, and monofunctionality.

First is a progressive adaptation of the city to car-based transport. In the effort to deliver car-based convenience, the carpark is inserted between the street and the shops - in many cases the sidewalk is no longer a retail frontage and often disappears entirely. The capacity to walk from the surrounding neighbourhood may or may not be retained. As more and more land is consumed for carparking, the density of retail development generally declines. Second is a morphological transformation from a proliferation of small-grain stores to a mix of small- and large-grain stores incorporating the department store and big box. The next is a progressive centralisation of ownership. This process begins in the department store in which centralised ownership is established to manage a range of product departments. This is then practiced at larger scales by the shopping mall and power centre where substantial urban territories come under single ownership. This centralisation of ownership is associated with a progressive privatization of shopping space. The legal public-private interface moves away from the shopfront so that any social interaction takes place in quasi-public space of public access under private control. This process begins in the arcade where a quasi-public realm is created as a linkage 
through the public network. In the strips, strip malls, suburban malls, and power centres the public/private interface moves to the carpark entry and the quasi-public retail interface is no longer part of a shortcut but a cul-de-sac - the experience of shopping becomes disintegrated from the city. This disintegration also involves a shift from a mixing of shopping with other functions (community, public buildings, offices, and residences) into largely mono-functional zones. The traditional types are often part of a vertical and intricate mix of functions on the same site (Hakim 1986; Mumford 1961; Wang 2003) while the 20th century types are rarely mixed (Sudjic 1992). Shopping malls and their adaptations can be vertically mixed with working (e.g. corporate tower) and living (e.g. luxury hotel) functions. However, such a vertical mix is often a pre-conceived co-existence of various functions, and largely acts as an urban enclave that is rooted in the quasi-public 'dream world' of the shopping mall rather than the public city (Garreau 1991; Goss 1993; Jewell 2015).

Thus, in general terms this genealogy reveals a pattern whereby urban retailing becomes more cardependent, centralized, privatized, disintegrated, mono-functional and lumpy. The 20th century retail types represent a challenge for retail planning and for urban design thinking in general since they cut across the values of a walkable, integrated, equitable and resilient city that have long been key imperatives of urban design (Jacobs 1961; Montgomery 1998). They entrench car-dependency within the morphology of the city and don't encourage walking except in the rather manipulative manner of the suburban mall (Dovey 2008). They are relatively unproductive because they are low-density and mono-functional cul-de-sacs within a sprawling metropolis that do not produce the intensive face-to-face urbanity of the most productive forms of urban life (Storper and Venables 2004). As the key exchange function of a city, shopping needs to be relatively dense and mixed with other functions in order to shrink distances and to benefit from the synergies that ensue from mixed-use. The modern retail types are disintegrated in the sense that the flows of the city do not pass through them. These types can also be socially inequitable because they often structure the city into socially exclusive zones, reducing the mixing of social classes that is produced in genuinely public space (Shields 1992). Public space is a space of learning and of engagement in public life and politics; in the quasi-public space of privatized shopping people learn only what has been permitted or curated in order to stimulate consumption (Dovey 2016; Sennett 2007; Zukin 1993).

\section{Discussion}

The goals of this paper are both descriptive and critical. First, a typology and genealogy of urban retail types are presented, showing how these types work diagrammatically and how different diagrams have been adapted and combined in the creation of new types. Second, the ways in which the 20th century types have damaged the walkability, productivity, and social equity of the city are critiqued - showing the imperative for further transformation. The diagrammatic typology of urban retailing is a means of organizing urban thinking, an attempt to understand the ways that urban retailing works through socio-spatial diagrams. These diagrams may well be seen as excessively reductive, however, it is not the goal here to reduce retailing to the diagrams so much as to reveal the ways that the same diagrams (patterns, types) can be seen to make urban retailing work at different scales and times. This paper first outlined four types that can be found in the traditional city: market (pedestrian network), plaza (field of vision with a fringe of shops), pedestrian street (pedestrian flow lined by stores) and main street (vehicular traffic and sidewalks). These types are then augmented in the 19th century with the arcade and department store. In the mid-20th century the rapid emergence of car-based retailing is shown through the key diagrammatic types of the strip, strip mall and shopping mall. These types transform modes of access (from walking to cars) and control (from fragmented to centralised; from public to private) as they implement modernist zoning codes (from mixed use to mono-functional).

While Pevsner (1976) notes how remarkable it is that shop types remained unchanged until the 19th century, this paper suggests that all of the retail types found in the traditional city can be seen diagrammatically 
as key drivers of the car-dependent types (Figure 7). Markets and plazas can be found within the shopping mall along with arcades and department stores. The power centre is the key innovation of the late 20th century, bringing together the convenience of the strip, strip mall and big box. While the shopping mall creates a facsimile of the traditional city with its markets, plazas and streets, the power centre can be understood as a giant plaza that has been privatized and motorized.

The contemporary urban designer has a conundrum - many urban areas have already been transformed by such modern retail types and there is no prospect of simply wishing them away. Yet this mix of low-density car-dependent development with centralized and privatized control, and large-grain monofunctional morphologies is a threat to the productive role of shopping in cities. It undermines urbanity - the very essence of what makes cities tick, and thus harms the resilience of urban shopping - the ability to adapt to shocks while fostering a viable retail economy and strong public urban life simultaneously (Rao and Summers 2016).With large land holdings under single ownership these retail types are vulnerable to the boom-bust cycles of neoliberal capital that can leave such projects and associated public investments underperforming - the 'dead mall' is "now a staple of North American (sub)urban landscapes" (Parlette and Cowen 2011, 794). A large number of big boxes have become bankrupted and then deserted as 'ghostboxes' (Hahn 2000; Schindler 2012), posing a danger to the power centre which now has a lifespan of less than half that of the shopping mall (Hahn 2000; Lowry 1997). Of course there can be no simple return to a traditional main street where there are also many examples in advanced states of dereliction.

While there are many cities and parts of cities that work well with traditional dense, mixed and walkable retailing, a key concern is with the future of run-down main streets, car-dependent shopping malls and power centres. The key challenge lies in trying to understand the prospects for new synergies, adaptations and mutations that might address these problems in a resilient way. It is necessary to look in particular at the key types of main street, shopping mall and power centre in terms of their capacity for further adaptation, and to investigate the ways in which new retail types with integrated mixed-use walkable neighbourhoods geared to public transit can emerge.

This process is of course well under way through a range of emergent retail types. Established main streets are frequently noticed to form various hybrids with shopping malls and their adaptations (Dovey 2016; Forsyth 1997; Jewell 2015; Southworth 2005; Thomas and Bromley 2003). Pre-conceived synergies between different retail types are also identified. 'Lifestyle centres' claim to reproduce a traditional town centre with main streets, pedestrian streets, plazas and functional mix (ICSC 2017; Southworth 2005). The 'theme shopping complex' inserts relatively spontaneous agglomerations of small-grain retailers with fragmented store ownership and a coordinated central management into an enclosed shopping area that is connected to carparks, and thus fosters a convergence between the pedestrian street, market, and shopping mall (Wang 1999; Wang and Xu 2002; Zhuang 2015).

It is beyond the scope of this paper to critique these emerging types or suggest particular transformations but five dimensions along which such transformations might effectively take place are suggested: carpark adaptation, densification, diversity of ownership, public control and land-use mix. Main street retailing dies for a range of reasons but it can be revived through new synergies with compact shopping malls and big box retailers, bringing car-based convenience to the more traditional retail type. Main streets can also be revived with public transport and higher densities of shop-top housing while maintaining diversity of ownership and public control.

For the large stand-alone shopping mall that is economically successful, the opportunity may be to integrate it into the larger city with a greater functional mix and less car-dependency. The greatest capacity to achieve this lies in the parking lots which need to be seen as opportunities for new publicly controlled urban 
development. The carpark land surrounding the private mall is ripe for transit-oriented redevelopment with a mix of residential, commercial and community uses. The vision is that the shopping mall remains profitable but becomes an integrated part of a genuinely public city - just like the arcade from which it was derived (Dovey and Woodcock 2014, 55-56). Power centres with their central carparks and big box stores are a different challenge. They are cheap to build (and to demolish) with concentrated ownership. If the location is right then there may be opportunities for the state to initiate transit-oriented development projects that will transform the most carbased of retail types into more resilient and integrated forms of public urbanity.

A key to unlocking capacity in all these retail types lies in the role of the state in providing high-volume public transport connections that assist to reduce car-dependency and therefore demand for parking. As the world passes what some call 'peak car' (Newman, Kenworthy, and Glazebrook 2013) and car-dependency declines, access to high-volume transit will become crucial to the economic viability of many such retail centres. The emergence of the autonomous car and a car-sharing economy will see new forms of transport emerge with less demand for parking. In the end what matters here is not the reproduction of particular types nor their genealogy, but the process through which new types are invented and tested in different cities and markets. The test lies not only in economic performance but in the ways retailing can be integrated with the design of a more productive, walkable, equitable and resilient city.

\section{References:}

Alexander, C., S. Ishikawa and M. Silverstein. 1977. A pattern language: Towns, buildings, construction. New York: Oxford University Press.

Arnold, S. J. and M.N. Luthra. 2000. "Market entry effects of large format retailers: A stakeholder analysis." International Journal of Retail \& Distribution Management 28(4/5): 139-154.

Berry, B.J.L. 1967. Geography of market centers and retail distribution. Englewood Cliffs: Prentice-Hall.

Crawford, M. 1992. "The world in a shopping mall". In Variations on a theme park: The new American city and the end of public space, ed. Sorkin, M, 3-30. New York: Hill and Wang.

DeLanda, M. 2006. A new philosophy of society: Assemblage theory and social complexity. London: Continuum.

Deleuze, G. and F. Guattari. 1987. A thousand plateaus: Capitalism and schizophrenia. Translated by Brian Massumi. Minneapolis: University of Minnesota Press.

Dovey, K. 2008. Framing places: Mediating power in built form. London: Routledge.

Dovey, K. 2010. Becoming places: Urbanism/architecture/identity/power. London: Routledge.

Dovey, K. 2016. Urban design thinking: A conceptual toolkit. London: Bloomsbury.

Dovey, K. and I. Woodcock. 2014. Intensifying Melbourne: Transit-oriented urban design for resilient urban futures. Research report. Melbourne: University of Melbourne.

www.msd.unimelb.edu.au/sites/default/files/docs/Intensifying\%20Melbourne\%202014_180dpi.pdf (accessed 6 September 2017)

Fernie, J. 1998. "The breaking of the fourth wave: Recent out-of-town retail developments in Britain." The International Review of Retail, Distribution and Consumer Research 8(3): 303-317.

Ford, L. 2003. America's new downtowns: Revitalization or reinvention? Baltimore: Johns Hopkins University Press.

Forsyth, A. 1997. "Variations on a main street: When a mall is an arcade." Journal of Urban Design 2(3): 297307.

Frieden, B.J. and L.B. Sagalyn. 1989. Downtown, inc. : How America rebuilds cities. Cambridge: MIT Press.

Garreau, J. 1991. Edge city: Life on the new frontier. New York: Doubleday.

Geist, J.F. 1983. Arcades, the history of a building type. Cambridge: MIT Press.

Gibbs, R.J. 2012. Principles of urban retail planning and development. Hoboken: John Wiley \& Sons.

Goss, J. 1993. "The "magic of the mall": An analysis of form, function, and meaning in the contemporary retail built environment." Annals of the Association of American Geographers 83(1): 18-47.

Gruen, V. and L. Smith. 1960. Shopping towns USA: The planning of shopping centers. New York: Reinhold. 
Guy, C. 1998. "Classifications of retail stores and shopping centres: Some methodological issues." GeoJournal 45(4): 255-264.

Hahn, B. 2000. "Power centres: A new retail format in the United States of America." Journal of Retailing and Consumer Services 7(4): 223-231.

Hakim, B.S. 1986. Arabic-Islamic cities: Building and planning principles. London: KPI Limited.

Herman, D. 2001. "Jerde transfer". In Harvard Design School guide to shopping, eds Chung, C.J., Inaba, J., Koolhaas, R. and Leong, S.T., 129-56. Cambridge: Taschen.

Hernandez, T., T. Lea, A. Spagnolo and A. Maze. 2004. "Shopping centers, power retailing and evolving retail environments: A comparison of the retail markets of Dallas-Fort Worth and Toronto." Journal of Shopping Center Research 11(1): 55-112.

ICSC (International Council of Shopping Centers). 2017. U. S. Shopping center classification and characteristics. http://www.icsc.org/uploads/research/general/US_CENTER_CLASSIFICATION.pdf (accessed 8 May 2017).

Jacobs, J. 1961. The death and life of great American cities. New York: Random House.

Jakle, J.A. and R.L. Mattson. 1981. "The evolution of a commercial strip." Journal of Cultural Geography 1(2): 1225.

Jewell, N. 2015. Shopping malls and public space in modern China. Burlington: Ashgate.

Jones, K. and M. Doucet. 2000. "Big-box retailing and the urban retail structure: The case of the Toronto area." Journal of Retailing and Consumer Services 7(4): 233-247.

Kostof, S. 1991. The city shaped: Urban patterns and meanings through history. London: Thames \& Hudson.

Leong, S.T. 2001. "And then there was shopping”. In Harvard Design School guide to shopping, eds Chung, C.J., Inaba, J., Koolhaas, R. and Leong, S.T., 129-156. Cambridge: Taschen.

Longstreth, R.W. 1997. City center to regional mall: Architecture, the automobile, and retailing in Los Angeles, 1920-1950. Cambridge: MIT Press.

Longstreth, R.W. 2010. The American department store transformed, 1920-1960. New Haven: Yale University Press.

Lorch, B. 2005. "Auto-dependent induced shopping: Exploring the relationship between power centre morphology and consumer spatial behaviour." Canadian Journal of Urban Research 14(2): 364-383.

Lowe, M. 2005. "The regional shopping centre in the inner city: A study of retail-led urban regeneration." Urban Studies 42(3): 449-470.

Lowry, J.R. 1997. "The life cycle of shopping centers." Business Horizons 40(1): 77-86.

Marshall, S. 2005. Streets \& patterns. New York: Spon.

Montgomery, J. 1998. "Making a city: Urbanity, vitality and urban design." Journal of Urban Design 3(1): 93-116.

Moudon, A.V. 1994. "Getting to know the built landscape: Typomorphology". In Ordering space : Types in architecture and design, eds Franck, KA and Schneekloth, LH, 289-311. New York: Van Nostrand Reinhold.

Mumford, L. 1961. The city in history. London: Secker \& Warburg.

Newman, P., J. Kenworthy and G. Glazebrook. 2013. "Peak car use and the rise of global rail: Why this is happening and what it means for large and small cities". Journal of Transportation Technologies 3(4): 272-287.

Parlette, V. and D. Cowen. 2011. "Dead malls: Suburban activism, local spaces, global logistics." International Journal of Urban and Regional Research 35(4): 794-811.

Pevsner, N. 1976. A history of building types. Princeton: Princeton University Press.

Rao, F. and R.J. Summers. 2016. "Planning for retail resilience: Comparing Edmonton and Portland." Cities 58: 97-106.

Schindler, S.B. 2012. "The future of abandoned big box stores: Legal solutions to the legacies of poor planning decisions." University of Colorado Law Review 83: 471-548.

Sennett, R. 2007. "The open city". In The endless city, ed. Burdett, R. and Sudjic, D., 290-298. London: Phaidon. 
Shields, R. 1992. "Spaces for the subject of consumption". In Lifestyle shopping: The subject of consumption, ed. Shields, R., 1-20. London: Routledge.

Southworth, M. 2005. "Reinventing main street: From mall to townscape mall." Journal of Urban Design 10(2): 151-170.

Storper, M. and A.J. Venables. 2004. "Buzz: Face-to-face contact and the urban economy." Journal of Economic Geography 4(4): 351-370.

Sudjic, D. 1992. The 100 mile city. San Diego: Harcourt Brace.

Teller, C. 2008. "Shopping streets versus shopping malls - determinants of agglomeration format attractiveness from the consumers' point of view." The International Review of Retail, Distribution and Consumer Research 18(4): 381-403.

Thomas, C.J. and R.D.F. Bromley. 2003. "Retail revitalization and small town centres: The contribution of shopping linkages." Applied Geography 23(1): 47-71.

Thomas, C.J., R.D.F. Bromley and A.R. Tallon. 2004. "Retail parks revisited: A growing competitive threat to traditional shopping centres?" Environment and Planning A 36(4): 647-666.

Vance J.E. 1990. The continuing city: Urban morphology in western civilization. Baltimore: Johns Hopkins University Press.

Venturi, R., D. Scott Brown and S. Izenour. 1977. Learning from Las Vegas: The forgotten symbolism of architectural form. Cambridge: MIT Press.

Wang, D. 2003. Street culture in Chengdu : Public space, urban commoners, and local politics, 1870-1930. Stanford: Stanford University Press.

Wang, J.J. and J. Xu. 2002. "An unplanned commercial district in a fast-growing city: A case study of Shenzhen, China." Journal of Retailing and Consumer Services 9(6): 317-326.

Wang, S. 1999. "Chinese commercial activity in the Toronto CMA: New development patterns and impacts." Canadian Geographer 43(1): 19-35.

Zhuang, Z.C. 2015. "Construction and reconstruction of ethnicity in retail landscapes: Case studies in the Toronto area." Journal of Urban Design 20(5): 677-697.

Zukin, S. 1993. Landscapes of power: From Detroit to Disney World. Berkeley: University of California Press. 